\title{
Actinomycetes from the Red Sea Sponge Coscinoderma mathewsi: Isolation, Diversity, and Potential for Bioactive Compounds Discovery
}

\author{
Yara I. Shamikh ${ }^{1,2,+} \mathbb{D}$, Aliaa A. El Shamy ${ }^{3,+}$, Yasser Gaber ${ }^{4,5}{ }^{\mathbb{D}}$, \\ Usama Ramadan Abdelmohsen 6,7,8 ${ }^{\mathbb{D}}$, Hashem A. Madkour ${ }^{9}$, Hannes Horn ${ }^{10} \mathbb{D}$, \\ Hossam M. Hassan ${ }^{11}\left(\mathbb{D}\right.$, Abeer H. Elmaidomy ${ }^{11} \mathbb{D}$, Dalal Hussien M. Alkhalifah ${ }^{12}$ and \\ Wael N. Hozzein 13,14,*(D)
}

1 Department of Microbiology and Immunology, Nahda University in Beni Suef, Beni-Suef 65211, Egypt; yara.shamikh@nub.edu.eg

2 Consultant, Virology Department, Egypt Center for Research and Regenerative Medicine (ECRRM), Cairo 11517, Egypt

3 Department of Microbiology and Public Health, Faculty of Pharmacy, Heliopolis University for Sustainable Development, Cairo 11785, Egypt; aliaa.ali@hu.edu.eg

4 Department of Microbiology and Immunology, Faculty of Pharmacy, Beni-Suef University, Beni-Suef 62511, Egypt; yasser.gaber@pharm.bsu.edu.eg

5 Department of Pharmaceutics and Pharmaceutical Technology, College of Pharmacy, Mutah University, Karak 61710, Jordan

6 Department of Pharmacognosy, Faculty of Pharmacy, Minia University, Minia 61519, Egypt; usama.ramadan@mu.edu.eg

7 Department of Pharmacognosy, Faculty of Pharmacy, Deraya University, 7 Universities Zone, New Minia 61111, Egypt

8 Department of Pharmacognosy, College of Pharmacy, King Khalid University, Abha 61441, Saudi Arabia

9 Department of Marine and Environmental Geology, National Institute of Oceanography and Fisheries, Red Sea Branch, Hurghada 84511, Egypt; madkour_hashem@yahoo.com

10 Independent Researcher, 69126 Heidelberg, Germany; hannesdhorn@gmail.com

11 Department of Pharmacognosy, Faculty of Pharmacy, Beni-Suef University, Beni-Suef 62511, Egypt; abuh20050@yahoo.com (H.M.H.); abeerabdelhakium@yahoo.com (A.H.E.)

12 Biology Department, College of Science, Princess Nourah Bint Abdulrahman University, Riyadh 11451, Saudi Arabia; DHALkalifah@pnu.edu.sa

13 Bioproducts Research Chair, Zoology Department, College of Science, King Saud University, Riyadh 11451, Saudi Arabia

14 Botany and Microbiology Department, Faculty of Science, Beni-Suef University, Beni-Suef 62521, Egypt

* Correspondence: whozzein@ksu.edu.sa

+ These authors contributed equally to this work.

Received: 15 April 2020; Accepted: 21 May 2020; Published: 23 May 2020

Abstract: The diversity of actinomycetes associated with the marine sponge Coscinoderma mathewsi collected from Hurghada (Egypt) was studied. Twenty-three actinomycetes were separated and identified based on the $16 \mathrm{~S}$ rDNA gene sequence analysis. Out of them, three isolates were classified as novel species of the genera Micromonospora, Nocardia, and Gordonia. Genome sequencing of actinomycete strains has revealed many silent biosynthetic gene clusters and has shown their exceptional capacity for the production of secondary metabolites, not observed under classical cultivation conditions. Therefore, the effect of mycolic-acid-containing bacteria or mycolic acid on the biosynthesis of cryptic natural products was investigated. Sponge-derived actinomycete Micromonospora sp. UA17 was co-cultured using liquid fermentation with two mycolic acid-containing actinomycetes (Gordonia sp. UA19 and Nocardia sp. UA 23), or supplemented with pure mycolic acid. LC-HRESIMS data were analyzed to compare natural production across all crude extracts. Micromonospora sp. UA17 was rich with isotetracenone, indolocarbazole, and anthracycline 
analogs. Some co-culture extracts showed metabolites such as a chlorocardicin, neocopiamycin A, and chicamycin B that were not found in the respective monocultures, suggesting a mycolic acid effect on the induction of cryptic natural product biosynthetic pathways. The antibacterial, antifungal, and antiparasitic activities for the different cultures extracts were also tested.

Keywords: sponges; actinomycetes; cryptic; Micromonospora; Nocardia; Gordonia; mycolic acid; LC-HRESIMS

\section{Introduction}

Actinomycetes are Gram-positive bacteria living in a wide range of aquatic, terrestrial environments and produce a variety of diverse bioactive compounds [1-4]. This phylum also has been found in a range of marine organisms such as corals, sponges, and jellyfish [5-7]. Actinomycetes from the marine environment have been reported to produce most of the bioactive compounds identified from the marine ecosystems [8,9]. These compounds belong to a variety of classes including polyketides, alkaloids, fatty acids, peptides, and terpenes [10-14]. There are many potential bioactivities of these compounds ranging from antibacterial, antifungal and antiparasitic to antioxidant and immunomodulatory activities [15-17]. With advances in sequencing technologies, actinomycete genomes have revealed many biosynthetic genes that encode for natural products not observed under standard fermentation conditions [18-22]. Previous methods were used to induce cryptic metabolites including chemical, molecular, and biological elicitation [22-29]. Altering the fermentation conditions ( $\mathrm{pH}$, media composition, and temperature) using the "one strain many compounds" (OSMAC) approach has been used to induce silent or poor expressed metabolic pathways [30-33]. Co-cultivation of microbial strains is a widely known approach to induce significant changes in the microbial metabolomes [20].

Mycolic acids are high-molecular-weight $\alpha$-branched, $\beta$-hydroxyl fatty acids, which are located in the cell wall of certain bacterial genera such as Corynebacterium, Mycobacterium Nocardia, Rhodococcus, and Segniliparus [34-36]. They play a major role in shaping the cell wall and protect against chemical substances [37,38]. The structure of each mycolic acid is thought to be genus-specific and differs in the length of the carbon chain $[34,39]$. For example, members of the genus Corynebacterium have $\mathrm{C}_{50}-\mathrm{C}_{56}$ and the genus Rhodococcus has been found to contain $\mathrm{C}_{34}-\mathrm{C}_{52}$. Onaka et al., 2011, reported the induction of a red pigment by Streptomyces lividans TK23 after co-cultivation with living cells of the mycolic acid-containing bacterium Tsukamurella pulmonis TP-B0596 [40]. It was shown that the metabolite profiles of several Streptomyces strains were changed after co-cultivation with the mycolic acid-containing bacterium T. pulmonis. Combined culture of S. endus S-522 with T. pulmonis resulted in the identification of a novel antibiotic, alchivemycin A [40]. Recently, Hoshino et al., 2015, isolated the di- and tri-cyclic macrolactams niizalactams A-C from the co-culture of Streptomyces sp. NZ-6 and the mycolic acid-containing bacterium Tsukamurella pulmonis TP-B0596 [41]. Arcyriaflavin E, a new cytotoxic indolocarbazole alkaloid, was isolated by co-cultivation of mycolic acid-containing bacteria and Streptomyces cinnamoneus NBRC 13823 [42]. Chojalactones A-C, cytotoxic butanolides were isolated from the co-culture of Streptomyces sp. cultivated with mycolic acid-containing bacterium Tsukamurella pulmonis TP-B0596 [43]. These studies highlight the efficacy of the co-cultivation strategy with mycolic acid-containing bacteria, for the discovery of cryptic natural products. Interestingly, all of those studies co-cultivate mycolic acid-containing bacteria with terrestrial actinomycetes however the effect on marine actinomycetes to our knowledge is yet to be investigated.

In this study, isolates of novel species belonging to the genera Micromonospora, Nocardia, and Gordonia were identified, and the effect of pure mycolic acid and mycolic acid-containing bacteria actinomycete Gordonia sp. UA19 and Nocardia sp. UA 23 on the secondary metabolite production of sponge-derived actinomycete Micromonospora sp. UA17 was examined by analyzing using 
LC-HRMS/MS data via metabolomes tools. The antibacterial, antifungal, and antiparasitic activities for the different cultures extracts were also tested.

\section{Materials and Methods}

\subsection{Description of the Area for Sponge Collection}

The study area lies about $5 \mathrm{~km}$ to the north of Hurghada at latitudes $27^{\circ} 17^{\prime} 01.0^{\prime \prime} \mathrm{N}$, and longitudes $33^{\circ} 46^{\prime} 21.0^{\prime \prime} \mathrm{E}$ (Figure 1). This site is characterized by a long patchy reef, representing the front edge of a wide and shallow reef flat with many depressions and lagoons. The depth ranged from about $3 \mathrm{~m}$ at the reef front with a gentle slope towards deep water. The area was exposed to strong waves, and the currents follow the prevailing current direction in the Red Sea from north to south. A medium development undergoes along the coast of this area. The bottom topography of this area is characterized by seagrasses and algae in intertidal and subtidal areas in addition to coral. The samples collected from this area, namely Ahia Reefs. Coscinoderma mathewsi was identified by El-Sayd Abed El-Aziz (Department of Invertebrates Lab., National Institute of Oceanography and Fisheries, Red Sea Branch, 84511 Hurghada, Egypt).
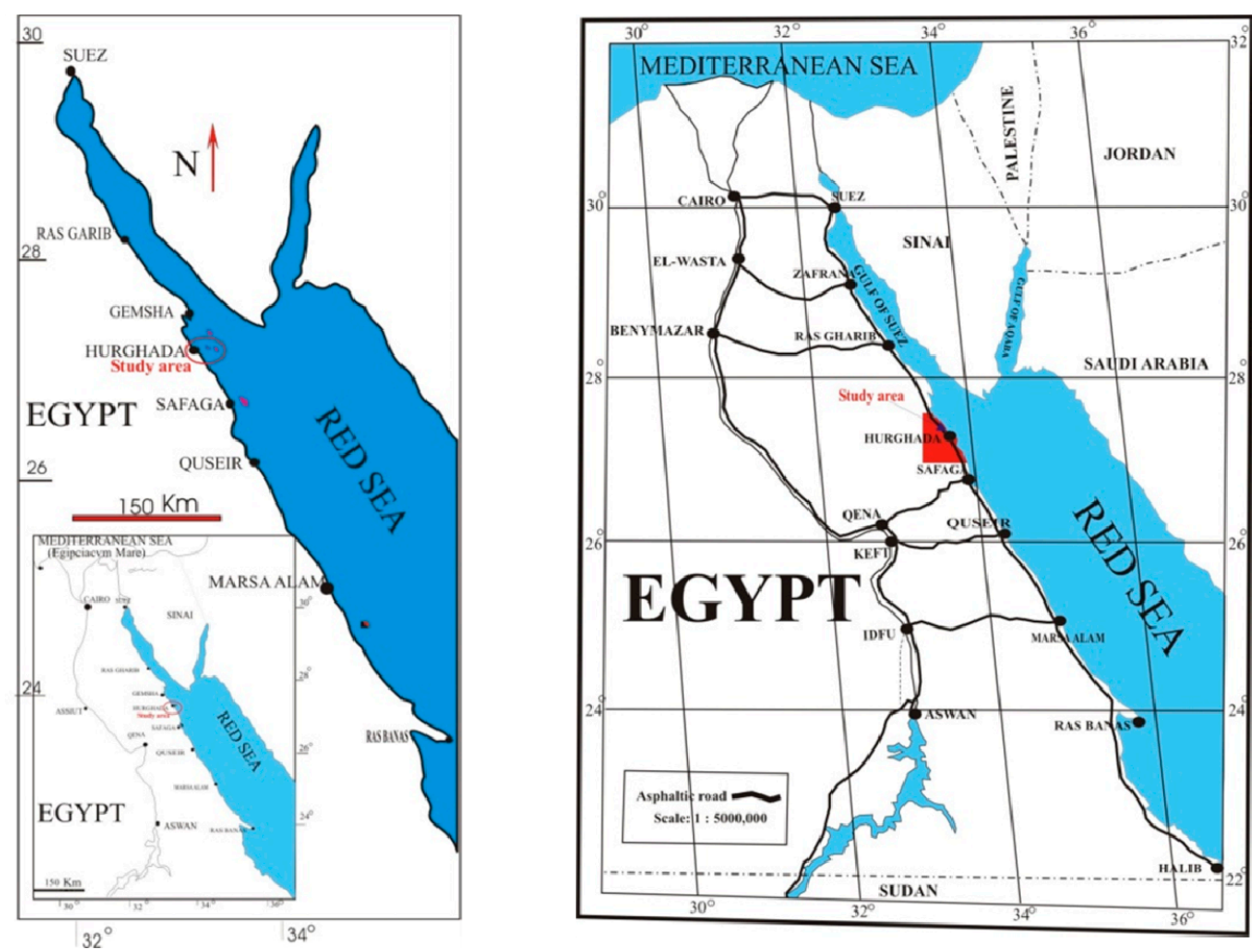

Figure 1. Location map of the study area along the Egyptian Red Sea coast.

\subsection{Chemicals and Reagents}

All chemicals were of high analytical grade, purchased from Sigma Chemical Co Ltd. (St. Louis, MO, USA).

\subsection{Actinomycetes Isolation}

The sponge biomass was transferred to the laboratory in a plastic bag containing seawater. Sponge specimens were washed with sterile seawater, cut into pieces of $\sim 1 \mathrm{~cm}^{3}$, and then thoroughly homogenized in a sterile mortar with 10 volumes of sterile seawater. The supernatant was serially diluted $\left(10^{-1}, 10^{-2}, 10^{-3}\right)$ and subsequently plated onto agar plates. Three different media (M1, ISP2, and Marine Agar (MA)) were used for the isolation of actinomycetes. All media were supplemented 
with $0.2 \mu \mathrm{m}$ pore size filtered cycloheximide $(100 \mu \mathrm{g} / \mathrm{mL})$, nystatin $(25 \mu \mathrm{g} / \mathrm{mL})$ and nalidixic acid $(25 \mu \mathrm{g} / \mathrm{mL})$ to facilitate the isolation of slow-growing actinomycetes. All media contained Difco Bacto agar $(18 \mathrm{~g} / \mathrm{L})$ and were prepared in $1 \mathrm{~L}$ artificial seawater $\left(\mathrm{NaCl} 234.7 \mathrm{~g}, \mathrm{MgCl}_{2} .6 \mathrm{H}_{2} \mathrm{O} 106.4 \mathrm{~g}, \mathrm{Na}_{2} \mathrm{SO}_{4}\right.$ $39.2 \mathrm{~g}, \mathrm{CaCl}_{2} 11.0 \mathrm{~g}, \mathrm{NaHCO}_{3} 1.92 \mathrm{~g}, \mathrm{KCl} 6.64 \mathrm{~g}, \mathrm{KBr} 0.96$ g, $\mathrm{H}_{3} \mathrm{BO}_{3} 0.26 \mathrm{~g}, \mathrm{SrCl}_{2}$ 0,24 g, NaF $0.03 \mathrm{~g}$ and $\mathrm{ddH}_{2} \mathrm{O}$ to $10.0 \mathrm{~L}$ ). The inoculated plates were incubated at $30{ }^{\circ} \mathrm{C}$ for $6-8$ weeks. Distinct colony morphotypes were picked and re-streaked until visually free of contaminants. Micromonospora sp. UA17, Gordonia sp. UA19 and Nocardia sp. UA 23 was cultivated on ISP2 medium. The isolates were maintained on plates at the fridge and in $20 \%$ glycerol at $-80^{\circ} \mathrm{C}$.

\subsection{Molecular Identification and Phylogenetic Analysis}

The systematic position of the $16 \mathrm{~S}$ rDNA sequences was analyzed with the SINA web aligner and the search and class option [44]. Closest relatives and type strains were obtained from GenBank using nucleotide Blast against nt and refseq_rna databases, respectively [45]. Alignments were calculated using again the SINA web aligner v1.2.11 (variability profile: bacteria). For maximum-likelihood tree construction RAxML v8.2.12 (-f a -m GTRGAMMA) was used with 100 bootstrap replicates [46]. Trees were visualized with interactive Tree of Life (iTol) v5.5 [47]. The 16S rDNA sequences of Micromonospora sp. UA17, Nocardia sp. UA23, and Gordonia sp. UA19 were deposited in GenBank under the accession numbers MT271359, MT271360, and MT271361.

\subsection{Co-cultivation and Extract Preparation}

Three actinomycetes were subjected to liquid fermentation as follows; each strain was fermented in 2 L Erlenmeyer flasks each containing $1.5 \mathrm{~L} \mathrm{ISP2} \mathrm{medium.} \mathrm{After} \mathrm{incubation} \mathrm{of} \mathrm{monocultures} \mathrm{and}$ co-cultures, the liquid cultures were grown for 10 days at $30^{\circ} \mathrm{C}$ while shaking at $150 \mathrm{rpm}$. The culture was then filtered and the supernatant was extracted with ethyl acetate. The ethyl acetate extracts were stored at $4{ }^{\circ} \mathrm{C}$. Mycolic acid was used at the concentration $(5 \mu \mathrm{g} / \mathrm{mL})$.

\subsection{Metabolic Profiling}

Ethyl acetate extracts from samples were prepared at $1 \mathrm{mg} / \mathrm{mL}$ for mass spectrometry analysis. The recovered ethyl acetate extract was subjected to metabolic analysis using LC-HR-ESI-MS according to Abdelmohsen et al. [33]. An Acquity Ultra Performance Liquid Chromatography system connected to a Synapt G2 HDMS quadrupole time-of-flight hybrid mass spectrometer (Waters, Milford, CT, USA) was used. Positive and negative ESI ionization modes were utilized to carry out the high-resolution mass spectrometry coupled with a spray voltage at $4.5 \mathrm{kV}$, the capillary temperature at $320^{\circ} \mathrm{C}$, and mass range from $\mathrm{m} / \mathrm{z}$ 150-1500. The MS dataset was processed and data were extracted using MZmine 2.20 based on the established parameters [48]. Mass ion peaks were detected and accompanied by chromatogram builder and chromatogram deconvolution. The local minimum search algorithm was addressed and isotopes were also distinguished via the isotopic peaks of grouper. Missing peaks were displayed using the gap-filling peak finder. An adduct search along with a complex search was carried out. The processed data set was next subjected to molecular formula prediction and peak identification. The positive and negative ionization mode data sets from the respective extract were dereplicated against the DNP (Dictionary of Natural Products) databases.

\subsection{Mycolic Acid Detection}

The existence of mycolic acid in the bacterial strains (Gordonia sp. UA19 and Nocardia sp. UA 23) was investigated following the protocol by Onaka et al., 2011 [40]. After 5-7 days fermentation, a broth culture $(50 \mathrm{~mL})$ was harvested and centrifuged ( $5000 \mathrm{rpm}$ for $15 \mathrm{~min})$, the resulting pellet was resuspended in $20 \mathrm{~mL}$ of $10 \% \mathrm{KOH}-\mathrm{MeOH}$ and then hydrolyzed by heating at $100{ }^{\circ} \mathrm{C}$ for $2 \mathrm{~h}$. The solution was cooled to room temperature, and the hydrolyzed residues were acidified with $6 \mathrm{~N}$ $\mathrm{HCl}$ and then extracted using $n$-hexane $(30 \mathrm{~mL})$. The hexane phase was collected and evaporated in vacuo. The residue was re-suspended in $20 \mathrm{~mL}$ of benzene-MeOH- $\mathrm{H}_{2} \mathrm{SO}_{4}$ (10:20:1) solution and 
incubated for $2 \mathrm{~h}$ at $100{ }^{\circ} \mathrm{C}$. The solution was cooled to room temperature, and the esterified residue was extracted using $20 \mathrm{~mL}$ of water and $n$-hexane (1:1). Mycolic acid was obtained by concentrating on the $n$-hexane phase. To confirm the extraction procedure, a hexane phase aliquot was subjected to thin-layer chromatography (TLC) (silica gel 60 F254; Merck); using an n-hexane-diethyl ether (4:1) mobile phase, and then dipped in $50 \% \mathrm{H}_{2} \mathrm{SO}_{4}$. The plates were heated at $150{ }^{\circ} \mathrm{C}$, and the methyl ester derivatives of mycolic acid were detected as brown colored spots.

\subsection{Antibacterial Activity}

Antibacterial activity was tested against Staphylococcus aureus NCTC 8325, Enterococcus faecalis, Escherichia coli and Pseudomonas aeruginosa (Culture Collections Public Health England, Porton Down, UK) [49]. After $24 \mathrm{~h}$ incubation at $37^{\circ} \mathrm{C}$, broth cultures were diluted in Müller-Hinton broth (1:100) and cultivated again until the cells reached the exponential growth phase. Cells $\left(10^{5} \mathrm{cells} / \mathrm{mL}\right)$ were incubated in the presence of various concentrations of the tested extracts in DMSO to the last volume of $200 \mu \mathrm{L}$ in a 96 -well plate at $37^{\circ} \mathrm{C}$. The final concentration of DMSO was $0.8 \%$ in each well. After $18 \mathrm{~h}$ of incubation, the optical density of the cultures was determined at $550 \mathrm{~nm}$ using an ELISA microplate reader (Dynatech Engineering Ltd., Willenhall, UK). The lowest concentration of the compound that inhibits bacterial growth was defined as the minimal inhibitory concentration (MIC), where chloramphenicol was used as a positive control $(0.3 \mu \mathrm{g} / \mathrm{mL})$.

\subsection{Antifungal Activity}

Antifungal activity was done by re-suspending a colony of Candida albicans 5314 (ATCC 90028) (Culture Collections Public Health England, Porton Down, UK) [50], in $2 \mathrm{~mL}$ of $0.9 \% \mathrm{NaCl}$. Four microliters of this suspension were transferred to $2 \mathrm{~mL}$ of HR medium. Various concentrations of the test extracts were diluted in $100 \mu \mathrm{L}$ of a medium in a 96-well microplate with a final DMSO concentration of $0.4 \%$. One hundred microliters of the Candida suspension were added to each well then incubated at $30{ }^{\circ} \mathrm{C}$ for $48 \mathrm{~h}$. Optical density was measured at $530 \mathrm{~nm}$ for control well without Candida cells, and the MIC was detected. Amphotericin B was used as a positive control (MIC $0.4 \mu \mathrm{g} / \mathrm{mL}$ ).

\subsection{Anti-Trypanosomal Activity}

The anti-trypanosomal activity was carried out according to the protocol of Huber and Koella using 104 trypanosomes per mL of Trypanosoma brucei brucei strain TC 221, which were cultivated in Complete Baltz Medium. Trypanosomes were tested in 96-well plate against different concentrations of test extracts at $10-200 \mu \mathrm{g} / \mathrm{mL}$ in $1 \%$ DMSO to a final volume of $200 \mu \mathrm{L}$. As a control, $1 \%$ DMSO and the parasite without the extract was used in each plate to show no effect of $1 \%$ DMSO. The plates were then incubated at $37^{\circ} \mathrm{C}$ in an atmosphere of $5 \% \mathrm{CO}_{2}$ for $24 \mathrm{~h}$. After the addition of $20 \mu \mathrm{L}$ of Alamar Blue, the activity was measured after 48 and $72 \mathrm{~h}$ by light absorption using an MR 700 Microplate Reader at a wavelength of $550 \mathrm{~nm}$ with a reference wavelength of $650 \mathrm{~nm}$. The MIC values of the test extracts were quantified in by linear interpolation of three independent measurements. Suramin was used as a positive control (MIC $0.23 \mu \mathrm{g} / \mathrm{mL}$ ).

\subsection{Statistical Analysis}

All experiments were carried out in triplicate. The data were presented as the means \pm standard error of the mean (SEM) of at least three independent experiments. The differences among various treatment groups were determined by ANOVA followed by Dunnett's test using PASW Statistics ${ }^{\circledR}$ version18 (Quarry Bay, Hong Kong). The difference of $p<0.05$ considered statistically significant compared with a vehicle-treated control group and showed by a symbol. The MIC values were determined using a nonlinear regression curve fitting analysis using GraphPad Prism software version 6 (La Jolla, CA, USA). 


\section{Results and Discussion}

\subsection{Molecular Identification and Phylogenetic Analysis}

The actinomycete diversity of the Red Sea sponge Coscinoderma mathewsi was investigated. Twenty-three isolates were selected based on their cultural characteristics appearance. The 16S rDNA genes were sequenced, and the resulted sequences were blasted against the GenBank database. The isolates were found to belong to six different genera, Gordonia, Kocuria, Nocardia, Micrococcus, Micromonospora, and Microbacterium. Three new species (Micromonospora sp. UA17, Gordonia sp. UA19, and Nocardia sp. UA 23) were identified based on sequence similarities $<98.2 \%$. The sequence similarities of the three isolates against the type strains ranging from $95.39 \%$ to $96.97 \%$ (Tables 1-3).

Table 1. List of validly published strains of genus Micromonospora. Identity calculated against strain Micromonospora sp. UA17.

\begin{tabular}{|c|c|c|c|c|}
\hline Isolate & Accession ID & Identity [\%] & Source & Ref \\
\hline $\begin{array}{l}\text { Micromonospora terminaliae DSM } \\
101760\end{array}$ & СР045309.1 & 96.678 & $\begin{array}{c}\text { Surface sterilized stem of Thai medicinal plant Terminalia } \\
\text { mucronata }\end{array}$ & [51] \\
\hline $\begin{array}{c}\text { Micromonospora inositola DSM } \\
43819\end{array}$ & LT607754.1 & 96.263 & $x_{0}$ & [52] \\
\hline Micromonospora cremea CR30 & NR_108478.1 & 96.258 & rhizosphere of Pisum sativum & [53] \\
\hline Micromonospora rosaria DSM 803 & NR_026282.1 & 96.125 & unknown & [54] \\
\hline $\begin{array}{c}\text { Micromonospora palomenae } \\
\text { NEAU-CX1 }\end{array}$ & NR_136848.1 & 96.055 & Nymphs of stinkbug (Palomena viridissima Poda) & [55] \\
\hline
\end{tabular}

Table 2. List of validly published strains of genus Gordonia. Identity calculated against strain Gordonia sp. UA19.

\begin{tabular}{|c|c|c|c|c|}
\hline Isolate & Accession ID & Identity [\%] & Source & Ref \\
\hline Gordonia hongkongensis HKU50 & NR_152023.1 & 95.386 & human blood culture & [56] \\
\hline Gordonia terrae 3612 & СР016594.1 & 95.320 & soil & [57] \\
\hline Gordonia bronchialis DSM 43247 & NR_074529.1 & 94.470 & human sputum & [58] \\
\hline Gordonia desulfuricans 213E & NR_028734.1 & 94.412 & soil & [59] \\
\hline Gordonia rubripertincta DSM 43248 & NR_043330.1 & 94.345 & soil & [60] \\
\hline
\end{tabular}

Table 3. List of validly published strains of genus Nocardia. Identity calculated against strain Nocardia sp. UA23.

\begin{tabular}{|c|c|c|c|c|}
\hline Isolate & Accession ID & Identity [\%] & Source & Ref \\
\hline Nocardia amikacinitolerans NBRC 108937 & NR_117564.1 & 96.972 & human eye (clinical isolate) & [62] \\
\hline Nocardia arthritidis DSM 44731 & NR_115824.1 & 96.898 & human sputum & [63] \\
\hline Nocardia araoensis NBRC 100135 & NR_118199.1 & 96.677 & human & [64] \\
\hline Nocardia beijingensis DSM 44636 & NR_118618.1 & 96.529 & mud from a sewage ditch & NA \\
\hline
\end{tabular}

The phylogenetic tree for Micormonospora reveals the type strain Micromonospora terminaliae DSM 101760 to be the closest to Micromonospora sp. UA27 but did not show a specific cluster (Figure 2). The isolate Gordonia sp. UA19 was shown to be closest to the strain Gordonia sp. EG50, originally isolated from a marine sponge in the Red Sea and both seem to form an own cluster next to the obtained type strains (Figure 3). Isolate Nocardia sp. UA23 was placed with three strains, also isolated from marine sponges in either the Red Sea or the South China Sea (Figure 4). 


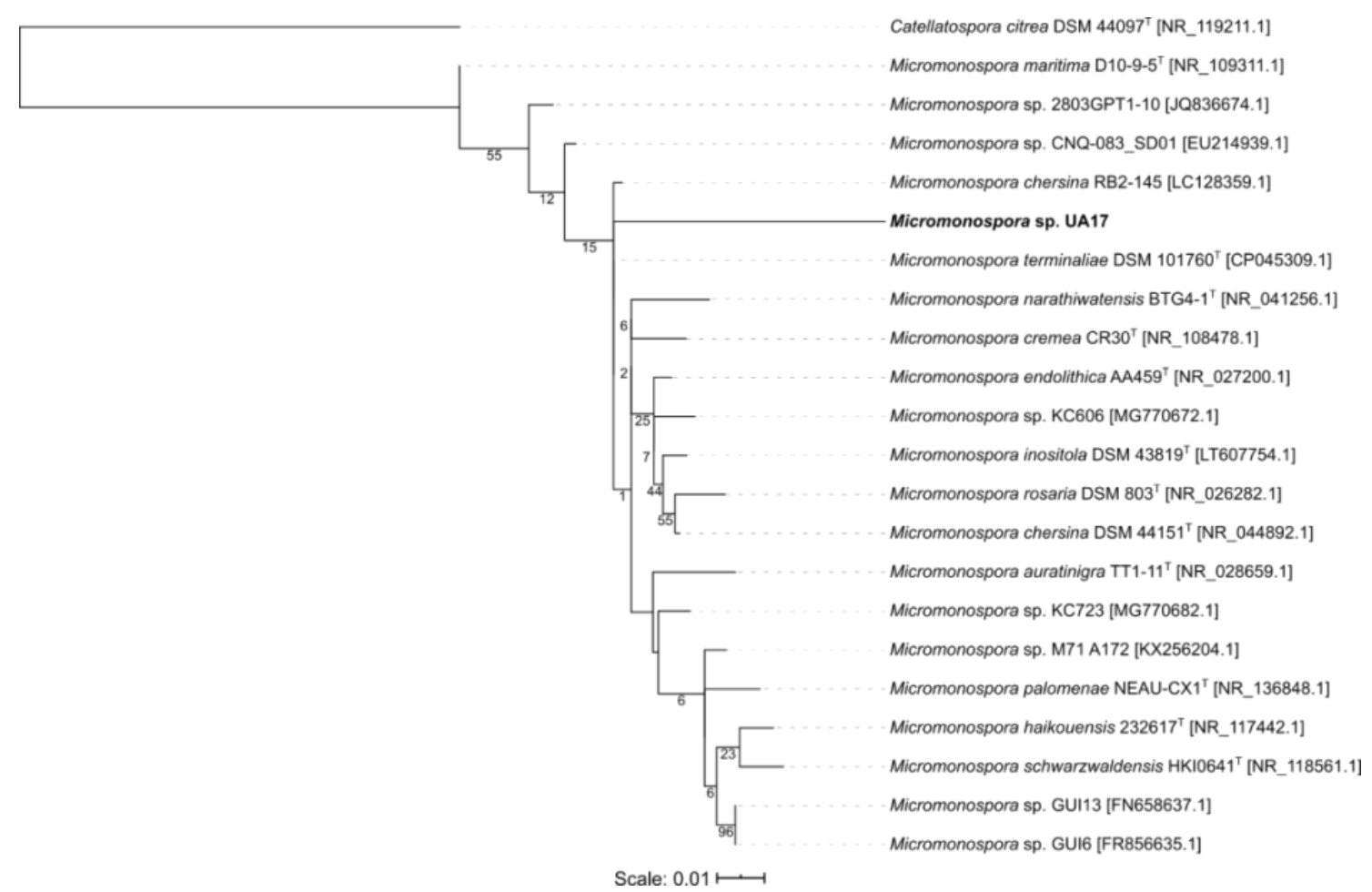

Figure 2. Maximum-likelihood tree of 21 Micromonospora representatives and one Catellatospora strain as an outgroup. Bootstrap values (100 resamples) are given in percent at the nodes of the tree. The isolate Micromonospora sp. UA17 obtained in this study is presented in bold.

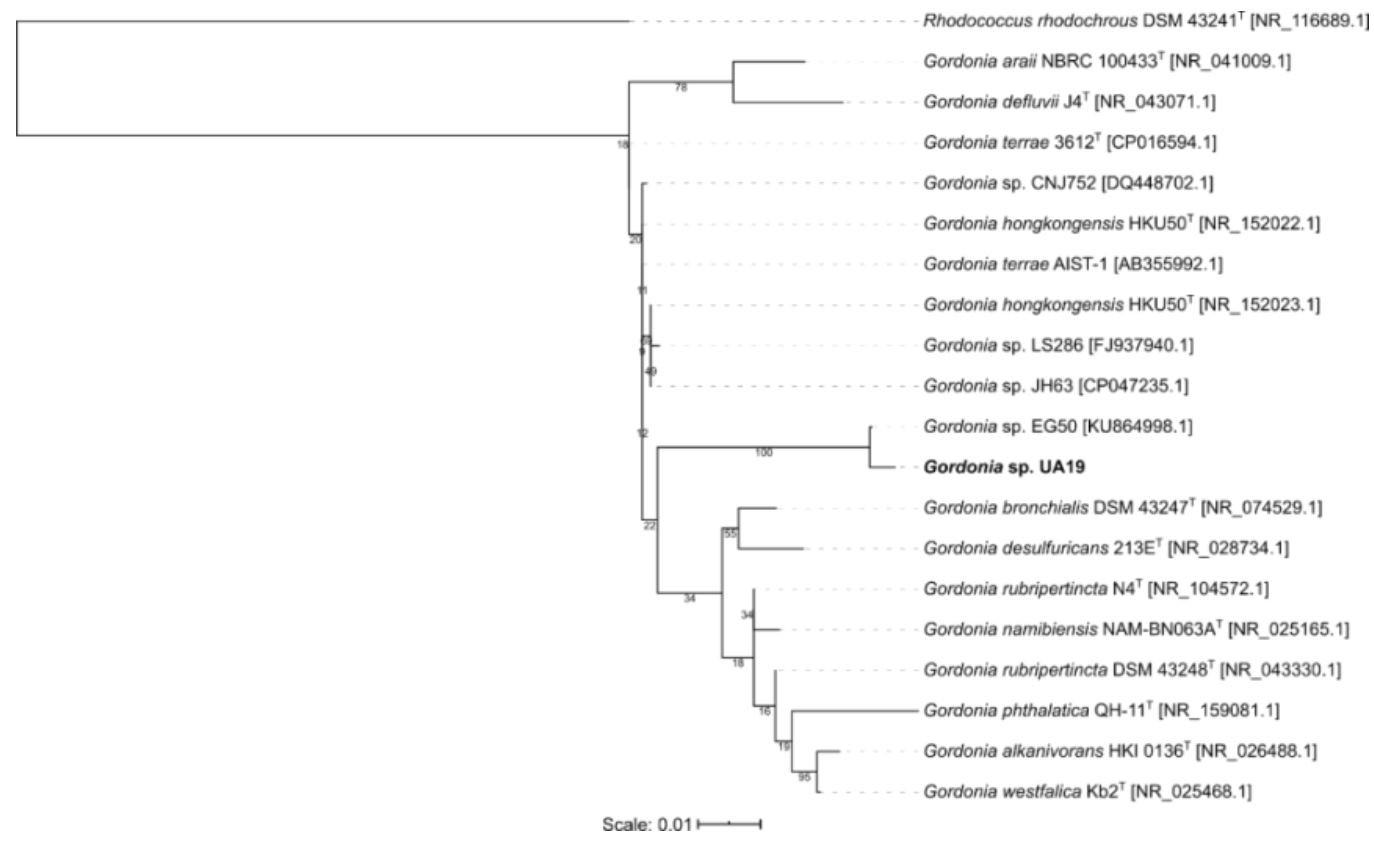

Figure 3. Maximum-likelihood tree of 19 Gordonia representatives and one Rhodococcus strain as an outgroup. Bootstrap values (100 resamples) are given in percent at the nodes of the tree. The isolate Gordonia sp. UA19 obtained in this study is presented in bold. 


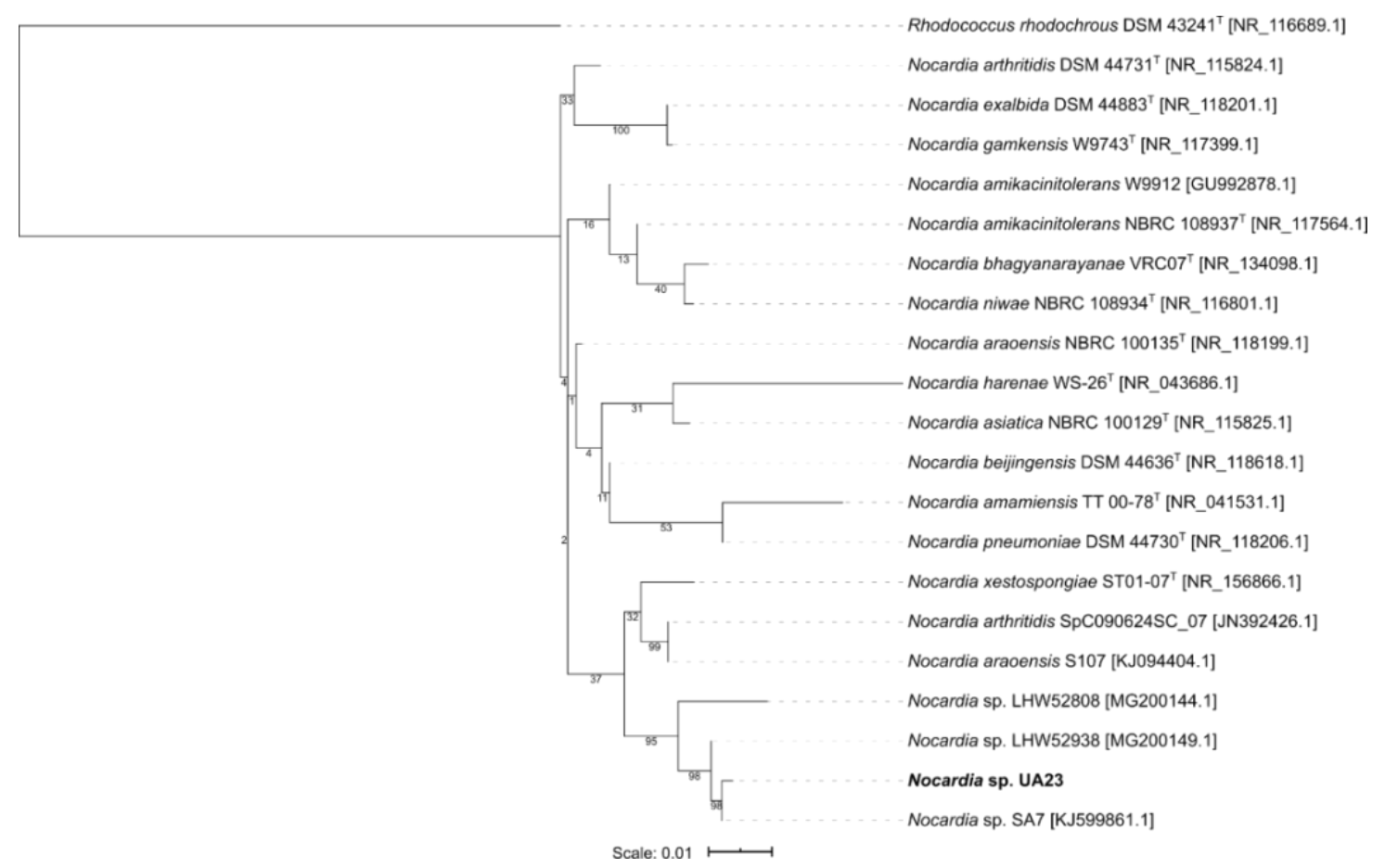

Figure 4. Maximum-likelihood tree of 20 Nocardia representatives and one Rhodococcus strain as an outgroup. Bootstrap values (100 resamples) are given in percent at the nodes of the tree. The isolate Nocardia sp. UA23 obtained in this study is presented in bold.

It has been noticed that the discovery and isolation of new secondary metabolites are becoming hard tasks, as many of the gene clusters encoding for proteins involved in the production of these compounds are normally silenced under lab cultivation conditions [22,65]. To activate these biosynthetic pathways, several strategies have been developed $[66,67]$. One of the most effective ones consists of the co-cultivation of different microorganisms. The fermentation of both microorganisms in a common environment creates a competitive interaction between them. This fight for survival may induce the synthesis of secondary metabolites that have a defending function against the other microorganism present in the culture medium, thus resulting in the silent activation of gene clusters. Another efficient method for inducing the production of cryptic secondary metabolites is the use of elicitors $[48,67,68]$. Elicitors are molecules that unregulate the expression of gene clusters involved in the biosynthesis of secondary metabolites in bacteria and fungi.

Sponge-derived actinomycete Micromonospora sp. UA17 was co-cultured using liquid fermentation with two mycolic acid-containing actinomycetes (Gordonia sp. UA19 and Nocardia sp. UA 23) or supplemented with pure mycolic acid. The crude extracts were tested against bacteria, fungi, and the human parasite Trypanosoma brucei.

\subsection{Metabolomic Profiling of Monoculture and Co-Culture Crude Extracts}

Metabolite profiles from crude extracts of the actinobacterial monoculture extracts (Micromonospora sp. UA17, Gordonia sp. UA19 and Nocardia sp. UA 23), besides co-cultures with two strains of mycolic acid-containing bacteria (Gordonia sp. UA19 and Nocardia sp. UA 23) and monocultures amended with mycolic acid were analyzed. The existence of mycolic acid in the selected strains was confirmed as described by Onaka et al., 2011 [40]. The richest metabolites (in terms of several metabolites produced) were observed when the strain Micromonospora sp. UA17 was co-cultured with Nocardia sp. UA 23 (which contains mycolic acid) or when supplemented with mycolic acid. 


\subsubsection{Chemical Dereplication of Micromonospora sp. UA17}

Analyzing the Micromonospora sp. UA17, several hits were proposed (Supplementary Table S1, Supplementary Figure S1a). The molecular ion mass peaks at $m / z$ 467.1350021, and 451.1401825 [M-H] $^{+}$, for the predicted molecular formulas $\mathrm{C}_{25} \mathrm{H}_{24} \mathrm{O}_{9}$ and $\mathrm{C}_{25} \mathrm{H}_{24} \mathrm{O}_{8}$ gave hits of the isotetracenone type antitumor antibiotics atramycin A (1), and B (2) (Supplementary Figure S1b) that were previously isolated from Streptomyces atratus [69]. The mass ion peak at $m / z$ 465.1557922, corresponding to the suggested molecular formula $\mathrm{C}_{27} \mathrm{H}_{22} \mathrm{~N}_{4} \mathrm{O}_{4}[\mathrm{M}-\mathrm{H}]^{+}$fit an antibiotic indolocarbazole derivative compound TAN-1030A (3) that was previously isolated from Streptomyces longisporoflavus R-19 [70]. The ion mass peak at $m / z 323.091309[\mathrm{M}+\mathrm{H}]^{+}$for the predicted molecular formulas $\mathrm{C}_{19} \mathrm{H}_{14} \mathrm{O}_{5}$ gave hits of the anthracyclinone antibiotic fujianmycin A (4) which was isolated from Streptomyces sp. GW71/2497 [71]. Two major ion peaks with the $m / z$ values of 529.171692 and 543.187439 [M-H] ${ }^{+}$ with molecular formulas $\mathrm{C}_{27} \mathrm{H}_{30} \mathrm{O}_{11}$ and $\mathrm{C}_{28} \mathrm{H}_{32} \mathrm{O}_{11}$ were detected and dereplicated as anthracycline antibiotic mutactimycin C (5) and A (6), respectively, which were isolated earlier from Streptomyces sp. 1254 [72]. In addition, the mass ion peaks at $m / z 479.171387[\mathrm{M}-\mathrm{H}]^{+}$, for the predicted molecular formula $\mathrm{C}_{28} \mathrm{H}_{24} \mathrm{~N}_{4} \mathrm{O}_{4}$ was dereplicated another antibiotic indolocarbazole derivative 7-Oxostaurosporine (7), which was previously detected in Streptomyces platensis, and reported as an inhibitor of protein kinase C (Figure S1b) [73].

\subsubsection{Chemical Dereplication of Gordonia sp. UA19}

Analyzing the Gordonia sp. UA19, few hits were proposed (Supplementary Table S2, Supplementary Figure S2a). The molecular ion mass peak at $m / z 199.0866394[\mathrm{M}+\mathrm{H}]^{+}$for the predicted molecular formulas $\mathrm{C}_{12} \mathrm{H}_{10} \mathrm{~N}_{2} \mathrm{O}_{2}$ gave hits of the 5-(3-indolyl)oxazole type antiviral pimprinine (8) (Supplementary Figure S2b) that were previously isolated from Streptomyces pimprina [74] and reported as inhibitors against the replication of EV71 and ADV-7 [75]. Other than indolocarbazole derivative founded in Micromonospora sp. UA17, which had promising activities, heroin the mass ion peak at $m / z 404.123993$ which corresponded to the suggested molecular formula $\mathrm{C}_{22} \mathrm{H}_{17} \mathrm{~N}_{3} \mathrm{O}_{5}[\mathrm{M}+\mathrm{H}]^{+}$fit an indenotryptoline compound-cladoniamide C (9) that was previously isolated from Streptomyces uncialis [76], and yet showed no activity. Additionally, atramycin A (1), B (2), and fujianmycin A (4) metabolites were also dereplicated based on the mass ion peaks and in agreement with the molecular formulas.

\subsubsection{Chemical Dereplication of Nocardia sp. UA 23}

When analyzing the Nocardia sp. UA 23, several hits were proposed (Supplementary Table S3, Supplementary Figure S3a,b). The molecular ion mass peak at $m / z 161.08075[\mathrm{M}+\mathrm{H}]^{+}$for the predicted molecular formula $\mathrm{C}_{7} \mathrm{H}_{12} \mathrm{O}_{4}$ gave hits of the carbasugar gabosine- $\mathrm{B}$ (10) that were previously isolated from Streptomyces albus [77] and reported as having DNA-binding properties [78]. The molecular ion mass peaks at $m / z 397.093338[\mathrm{M}-\mathrm{H}]^{+}$for the predicted molecular formula $\mathrm{C}_{22} \mathrm{H}_{14} \mathrm{~N}_{4} \mathrm{O}_{4}$ gave hits of the quinoline-5,8-diones type antitumor antibiotic lavendamycin (11) that was previously isolated from Streptomyces lavendulae C-22030 S [79]. The mass ion peak at $m / z 300.049118$, corresponding to the suggested molecular formula $\mathrm{C}_{10} \mathrm{H}_{12} \mathrm{ClN}_{5} \mathrm{O}_{4}[\mathrm{M}-\mathrm{H}]^{+}$fits the purine derivative 2-chloroadenosine (12) that was previously isolated from Streptomyces rishiriensis 265, Sp-265 (FERM-p 5921) [80] and reported as having a suppression effect in seizure [81]. The molecular ion mass peaks at $m / z 249.107941$ $[\mathrm{M}+\mathrm{H}]^{+}$for the predicted molecular formula $\mathrm{C}_{9} \mathrm{H}_{16} \mathrm{~N}_{2} \mathrm{O}_{6}$ gave hits of the amino acid antibiotic malioxamycin (13) that was previously isolated from Streptomyces lydicus [82] and reported as having a role in the management of Streptococcus pneumoniae infection [83]. In addition, the mass ion peaks at $m / z 407.167511[\mathrm{M}-\mathrm{H}]^{+}$for the predicted molecular formula $\mathrm{C}_{16} \mathrm{H}_{28} \mathrm{~N}_{2} \mathrm{O}_{10}$ was dereplicated as Enkastine I (14), which was a glycopeptide derivative, and was previously detected in Streptomyces albus ATCC 21838 [84]. According to the literature, Enkastine I was reported as a potent inhibitor of the endopeptidase 24.11, with an $\mathrm{IC}_{50}$ of $1.8 \times 10^{-9} \mathrm{M}$ [84]. Likewise, the molecular formula $\mathrm{C}_{14} \mathrm{H}_{18} \mathrm{~N}_{2} \mathrm{O}_{5}$ was characterized as the antitumor antibiotic benzodiazepine derivative chicamycin $A(\mathbf{1 5})$, from the 
mass ion peak at $m / z 293.1146317$ [M-H] $]^{+}$, which was previously obtained from Streptomyces albus [85,86]. The mass ion peaks at $m / z 279.0975189[\mathrm{M}+\mathrm{H}]^{+}$and $215.1289215[\mathrm{M}-\mathrm{H}]^{+}$in agreement with the predicted molecular formulas $\mathrm{C}_{13} \mathrm{H}_{14} \mathrm{~N}_{2} \mathrm{O}_{5}$, and $\mathrm{C}_{11} \mathrm{H}_{20} \mathrm{O}_{4}$, and were dereplicated as benzodiazepine antibiotic RK-1441B (16), and the aliphatic alcohol antidepressant ketalin (17), respectively. These metabolites have been isolated earlier from Streptomyces griseus [87], and Streptomyces lavendulae Tue 1668 [88,89], respectively. In addition, the mass ion peak at $m / z 1058.672668[\mathrm{M}+\mathrm{H}]^{+}$for the predicted molecular formula $\mathrm{C}_{54} \mathrm{H}_{95} \mathrm{~N}_{3} \mathrm{O}_{17}$ was dereplicated as macrolide derivative antibiotic copiamycin which has in vitro activity against Candida albicans, Torulopsis glabrata, and Trichomonas vaginalis. Lo (18) and was previously detected in Streptomyces hygroscopicus var. crystallogenes [90,91].

\subsubsection{Chemical Dereplication of Strains UA17 + UA19}

Analyzing co-culture Micromonospora sp. UA17 with mycolic acid-containing Gordonia sp. UA19 strain, interestingly dereplicated several hits (Supplementary Table S4, Supplementary Figure S4a, $\mathrm{S} 4 b)$. The molecular ion mass peak at $\mathrm{m} / \mathrm{z} 252.124252[\mathrm{M}-\mathrm{H}]^{+}$for the predicted molecular formula $\mathrm{C}_{13} \mathrm{H}_{19} \mathrm{NO}_{4}$ gave hits of the piperidine derivative MY 336a (19) that was previously isolated from Streptomyces gabonae [92]. The molecular ion mass peaks at $m / z 533.1067098[\mathrm{M}-\mathrm{H}]^{+}$for the predicted molecular formula $\mathrm{C}_{23} \mathrm{H}_{23} \mathrm{ClN}_{4} \mathrm{O}_{9}$ gave hits of the $\beta$-lactam derivative antibiotic chlorocardicin (20) that was previously isolated from Streptomyces spp. [93], and reported as an inhibitor to peptidoglycan biosynthesis [93]. The molecular ion mass peaks at $m / z 335.056519[\mathrm{M}-\mathrm{H}]^{+}$for the predicted molecular formula $\mathrm{C}_{19} \mathrm{H}_{12} \mathrm{O}_{6}$ gave hits of the benzo[a]anthracene derivative antibiotic WS 5995-A (21) that was previously isolated from Streptomyces auranticolor 5995 (FERM-p 5365) [94]. The molecular ion mass peaks at $m / z 1044.656982[\mathrm{M}+\mathrm{H}]^{+}$for the predicted molecular formula $\mathrm{C}_{53} \mathrm{H}_{93} \mathrm{~N}_{3} \mathrm{O}_{17}$ gave hits of the macrolide derivative Neocopiamycin A (22) that was previously isolated from Streptomyces hygroscopicus var. crystallogenes [95] and reported to be more active against Gram-positive bacteria and fungi but less toxic than copiamycin (18) [90]. The previously identified metabolites atramycin A (1), B (2), pimprinine (8), and copiamycin (18), were also dereplicated based on the mass ion peaks and in agree with the molecular formulas.

\subsubsection{Chemical Dereplication of Strains UA17 + UA23}

Analyzing co-culture Micromonospora sp. UA17 with mycolic acid-containing Nocardia sp. UA 23 strain, dereplicated several hits (Supplementary Table S5, Supplementary Figure S5a,b). A compound at $m / z 215.1390686[\mathrm{M}+\mathrm{H}]^{+}$, corresponding to the suggested molecular formula $\mathrm{C}_{10} \mathrm{H}_{18} \mathrm{~N}_{2} \mathrm{O}_{3}$ was dereplicated as Alkaloid derivative LL-BH-872 $\alpha$ (23), which was formerly reported from Streptomyces hinnulinus [96]. The mass ion peaks at $m / z$ 247.1076736, 276.170578, 280.082809, 224.0916748, and 261.0881348 for the predicted molecular formulas $\mathrm{C}_{13} \mathrm{H}_{14} \mathrm{~N}_{2} \mathrm{O}_{3}, \mathrm{C}_{15} \mathrm{H}_{21} \mathrm{~N}_{3} \mathrm{O}_{2}, \mathrm{C}_{13} \mathrm{H}_{15} \mathrm{NO}_{6}$, $\mathrm{C}_{11} \mathrm{H}_{13} \mathrm{NO}_{4}$, and $\mathrm{C}_{13} \mathrm{H}_{14} \mathrm{~N}_{2} \mathrm{O}_{4}$ were dereplicated as benzodiazepine DC 81 (24), eserine Alkaloid (25), amino derivative 13-hydroxy-streptazolin (26), pyridine-piperidine derivative A 58365B (27), and also benzodiazepine antitumor antibiotic chicamycin B (28), respectively, which were previously detected in Streptomyces roseiscleroticus do-81 (FERM-p 6502) [97], Streptomyces griseofuscus [98], Streptomyces chromofuscus [99], Streptomyces sp. A1 [100], and Streptomyces albus [86], respectively. Whereas that at $m / z 229.1546555$, corresponding to the suggested molecular formula $\mathrm{C}_{11} \mathrm{H}_{20} \mathrm{~N}_{2} \mathrm{O}_{3}$ was dereplicated as imidazolidine derivative Libramycin-A (29), which was formerly reported from Streptomyces sp. [101]. Likewise, the molecular formulas $\mathrm{C}_{16} \mathrm{H}_{27} \mathrm{~N}_{3} \mathrm{O}_{6}$, and $\mathrm{C}_{11} \mathrm{H}_{11} \mathrm{NO}_{5}$ was characterized as $\beta$-propiolactone amino acid belactosin $\mathrm{C}$ (30), and dehydrodioxolide B alkaloids (31), from the mass ion peaks at $m / z$ 356.183197, and 236.0565987, which was previously obtained from Streptomyces sp. KY11780 [102], and Streptomyces tendae [103], respectively. Moreover, the characteristic metabolites atramycin A (1), chicamycin A (15), and chlorocardicin (20) were also dereplicated based on the mass ion peaks and in agreement with the molecular formulas. 


\subsubsection{Chemical Dereplication of Strain UA17 with Mycolic Acid}

Analyzing co-culture Micromonospora sp. UA17 with mycolic acid, dereplicated several hits (Supplementary Table S6, Supplementary Figure S6a,b). A compound at $m / z$ 213.102264, corresponding to the suggested molecular formula $\mathrm{C}_{13} \mathrm{H}_{12} \mathrm{~N}_{2} \mathrm{O}$ was dereplicated as 5-(3-indolyl)oxazole derivative antiviral pimprinethine (32), which was formerly reported from Streptoverticillium olivoreticuli [75,104]. The mass ion peaks at $\mathrm{m} / \mathrm{z}$ 259.1089478, 190.049843, 227.1178055, and 238.0722198 for the predicted molecular formulas $\mathrm{C}_{14} \mathrm{H}_{16} \mathrm{~N}_{2} \mathrm{O}_{3}, \mathrm{C}_{10} \mathrm{H}_{7} \mathrm{NO}_{3}, \mathrm{C}_{14} \mathrm{H}_{14} \mathrm{~N}_{2} \mathrm{O}$, and $\mathrm{C}_{11} \mathrm{H}_{13} \mathrm{NO}_{5}$ were dereplicated as diketopiperazine derivative maculosin (33), antioxidant 3-Hydroxyquinoline-2-carboxylic acid (34), benzodiazepine derivative antitumor antibiotic prothracarcin (35), and amino acid $\mathrm{N}$-acetyl-3,4-dihydroxy-L-phenylalanine (36), respectively which were previously detected in Streptomyces rochei 87051-3 [105], Streptomyces cyaneofuscatus M-157 [106,107], Streptomyces umbrosus [108,109], and Streptomyces akiyoshiensis ATCC13480 L127 mutants [110], respectively. Whereas that at $\mathrm{m} / \mathrm{z} 303.1353149$, corresponding to the suggested molecular formula $\mathrm{C}_{16} \mathrm{H}_{20} \mathrm{~N}_{2} \mathrm{O}_{4}$ was dereplicated as benzodiazepine derivative antitumor antibiotic tomaymycin (37), which was formerly reported from Streptomyces achromogenes-tomaymyceticus [111,112]. Likewise, the molecular formulas $\mathrm{C}_{16} \mathrm{H}_{25} \mathrm{~N}_{7} \mathrm{O}_{4} \mathrm{~S}, \mathrm{C}_{25} \mathrm{H}_{29} \mathrm{~N}_{3} \mathrm{O}_{10} \mathrm{~S}$ were characterized as purine derivative antibiotic cystocin (38), and $\beta$-lactam derivative deoxycephamycin B (39) from the mass ion peaks at $\mathrm{m} / \mathrm{z}$ 410.1608276, and 564.1655884 which were previously obtained from Streptomyces sp. GCA0001 [113] and Streptomyces olivaceus SANK 60384 (NRRL 3851) [114,115], respectively. Moreover, the characteristic metabolites, ketalin (17), chlorocardicin (20), DC 81 (24), eserine (25), 13-hydroxy-streptazolin (26), chicamycin B (28), libramycin-A (29), belactosin C (30), dehydrodioxolide B (31), were also dereplicated based on the mass ion peaks and in agreement with the molecular formulas.

\subsection{Antibacterial, Antifungal, and Anti-Trypanosomal Activities}

In this investigation, the crude extracts of the actinobacterial monoculture extracts (Micromonospora sp. UA17, Gordonia sp. UA19, and Nocardia sp. UA 23), beside co-cultures with two strains of mycolic acid-containing bacteria (Gordonia sp. UA19, and Nocardia sp. UA 23) and monocultures amended with mycolic acid were evaluated for their antibacterial, antifungal, and anti-trypanosomal activities against Staphylococcus aureus NCTC 8325, Escherichia coli, Pseudomonas aeruginosa, Candida albicans 5314, and Trypanosoma brucei TC 221, respectively. The results showed that Micromonospora sp. UA17 co-cultured with the two strains of mycolic acid-containing bacteria (Gordonia sp. UA19, and Nocardia sp. UA 23) and monocultures amended with mycolic acid were more active against Staphylococcus aureus NCTC 8325, Enterococcus faecalis, and Candida albicans 5314 compared with monoculture extracts, where UA17 + UA23 had recorded the highest inhibition activities with MIC value of 4.2,3.9, and $3.8 \mu \mathrm{g} / \mathrm{mL}$, respectively (Table 4). However, no activities were detected against Escherichia coli and Pseudomonas aeruginosa. These results suggest the mycolic acid affected the induction of bacterial natural product biosynthetic pathways. All tested extracts showed low activity against Trypanosoma brucei TC 221 (MIC $>100 \mu \mathrm{g} / \mathrm{mL}$ ), except Nocardia sp. UA 23 which recorded the highest inhibition activities with MIC value of $7.2 \mu \mathrm{g} / \mathrm{mL}$ (Table 4). 
Table 4. Results of the crude extracts of the actinobacterial monoculture extracts (Micromonospora sp. UA17, Gordonia sp. UA19, and Nocardia sp. UA 23), beside co-cultures with two strains of mycolic acid-containing bacteria (Gordonia sp. UA19, and Nocardia sp. UA 23) and monocultures amended with mycolic acid against Staphylococcus aureus NCTC 8325, Candida albicans 5314, and Trypanosoma brucei TC 221.

\begin{tabular}{|c|c|c|c|c|}
\hline \multirow[b]{2}{*}{ Sample Code } & \multicolumn{3}{|c|}{ MIC ( $\mu \mathrm{g} / \mathrm{mL})$} & \multirow{2}{*}{$\begin{array}{c}\mathrm{MIC}(\mu \mathrm{g} / \mathrm{mL}, 72 \mathrm{~h} .) \\
\text { Trypanosoma brucei TC } \\
221\end{array}$} \\
\hline & $\begin{array}{c}\text { Staphylococcus aureus } \\
\text { NCTC } 8325\end{array}$ & $\begin{array}{l}\text { Enterococcus } \\
\text { faecalis }\end{array}$ & $\begin{array}{c}\text { Candida } \\
\text { albicans } 5314\end{array}$ & \\
\hline $\begin{array}{c}\text { Micromonospora sp. } \\
\text { UA17 }\end{array}$ & 15.6 & 14.3 & 13.2 & $>100$ \\
\hline Gordonia sp. UA19 & 35.7 & 31.9 & 16.8 & $>100$ \\
\hline Nocardia sp. UA 23 & 38.9 & 39.2 & 25.7 & $7.2 *$ \\
\hline UA17 + UA19 & $8.6^{*}$ & $7.4^{*}$ & $6.4 *$ & $>100$ \\
\hline UA17 + UA23 & $4.2 *$ & $3.9 *$ & $3.8 *$ & $>100$ \\
\hline UA17 + Мyc & $4.7 *$ & $3.8 *$ & $5.9 *$ & $>100$ \\
\hline
\end{tabular}

MIC value of compounds against tested the microorganism, which was defined as minimal inhibitory concentration (MIC). Data were expressed as mean \pm 212 S.E.M $(n=3)$. One-way analysis of variance (ANOVA) followed by Dunnett's test was applied. Graph Pad Prism 5 was used for statistical calculations (Graph pad Software, San Diego, CA, USA). * Significant $(p<0.05)$.

\section{Conclusions}

The rapidly growing number of actinomycete genome sequences highlighted their potential for biosynthesizing a plethora of natural products that are much higher than expected during classical laboratory conditions. Biological elicitation (co-cultivation) of actinomycetes is an effective strategy to provoke the expression of unexpressed or poorly expressed secondary metabolites and further increasing their chemical diversity. This study highlighted the effect of co-culture with mycolic acid-producing microorganisms or mycolic acid itself in the induction of the biosynthesis of many metabolites; although they are known or previously isolated, it was first highlighted by this species because of the effect of co-culturing or the elicitor mycolic acid. On the other hand, some peaks showed no hits during dereplication which suggests they may be new metabolites and need further investigation in scale-up fermentation. The induction of these metabolites qualitatively and/or quantitatively may be the attributed to the difference in biological activities. As in Micromonospora sp. UA17 co-cultures with the two strains of mycolic acid-containing bacteria (Gordonia sp. UA19, and Nocardia sp. UA 23), monocultures amended with mycolic acid were more active against Staphylococcus aureus NCTC 8325, Enterococcus faecalis, and Candida albicans 5314 compared with monoculture extracts, where UA17 + UA23 had recorded the highest inhibition activities with MIC value of 4.2, 3.9, and $3.8 \mu \mathrm{g} / \mathrm{mL}$, respectively. These results suggest that mycolic acid affected the induction of bacterial natural product biosynthetic pathways. On the other hand, all tested extracts showed low activity against Trypanosoma brucei TC 221, except Nocardia sp. UA 23 which recorded the highest inhibition activity with an MIC value of $7.2 \mu \mathrm{g} / \mathrm{mL}$.

Supplementary Materials: The following are available online at http://www.mdpi.com/2076-2607/8/5/783/s1.

Author Contributions: Conceptualization: U.R.A. and H.M.H.; methodology: Y.I.S., U.R.A. and W.N.H.; software: U.R.A. and A.H.E.; formal analysis: A.H.E., A.A.E.S. and H.A.M.; investigation: U.R.A. and H.M.H.; resources: U.R.A. and H.H.; data curation: Y.G. and U.R.A.; writing-original draft: U.R.A. and A.H.E.; writing-review and editing: U.R.A., A.H.E., H.M.H. and W.N.H.; supervision: D.H.M.A. and W.N.H.; project administration: U.R.A.; funding acquisition: D.H.M.A. and W.N.H. All authors have read and agreed to the published version of the manuscript.

Funding: This research received no external funding.

Acknowledgments: This research was funded by the Deanship of Scientific Research at Princess Nourah bint Abdulrahman University through the Fast-track Research Funding Program. We thank M. Müller and M. Krischke (University of Würzburg) for LC-MS measurement.

Conflicts of Interest: The authors declare that no conflict of interest exist. 


\section{References}

1. Hameş-Kocabaş, E.E.; Ataç, U.Z.E.L. Isolation strategies of marine-derived actinomycetes from sponge and sediment samples. J. Microbiol. Methods 2012, 88, 342-347.

2. Adegboye, M.F.; Babalola, O.O. Taxonomy and ecology of antibiotic producing actinomycetes. Afr. J. Agric. Res. 2012, 15, 2255-2261.

3. Zhao, K.; Penttinen, P.; Guan, T.W.; Xiao, J.; Chen, Q.A.; Xu, J.; Lindstrom, K.; Zhang, L.L.; Zhang, X.P.; Strobel, G.A. The diversity and antimicrobial activity of endophytic actinomycetes isolated from medicinal plants in Panxi Plateau China. Curr. Microbiol. 2011, 62, 182-190. [CrossRef] [PubMed]

4. Ukhari, M.; Thomas, A.; Wong, N. Culture Conditions for Optimal Growth of Actinomycetes from Marine Sponges. In Developments in Sustainable Chemical and Bioprocess Technology; Springer: New York, NY, USA, 2013; pp. 203-210. [CrossRef]

5. Vicente, J.; Stewart, A.; Song, B.; Hill, R.T.; Wright, J.L. Biodiversity of Actinomycetes associated with Caribbean sponges and their potential for natural product discovery. Mar. Biotechnol. 2013, 15, 413-424. [CrossRef]

6. Sun, W.; Peng, C.S.; Zhao, Y.Y.; Li, Z.Y. Functional gene-guided discovery of type II polyketides from culturable actinomycetes associated with soft coral Scleronephthya sp. PLoS ONE 2012, 7, e42847. [CrossRef]

7. Cheng, C.; MacIntyre, L.; Abdelmohsen, U.R.; Horn, H.; Polymenakou, P.; Edrada-Ebel, R.; Hentschel, U. Biodiversity, anti-trypanosomal activity screening, and metabolomics profiling of actinomycetes isolated from Mediterranean sponges. PLoS ONE 2015, 10, e0138528. [CrossRef]

8. Abdelmohsen, U.R.; Bayer, K.; Hentschel, U. Diversity, abundance, and natural products of marine sponge-associated actinomycetes. Nat. Prod. Rep. 2014, 31, 381-399. [CrossRef]

9. Muller, R.; Wink, J. Future potential for anti-infectives from bacteria-how to exploit biodiversity and genomic potential. Int. J. Med. Microbiol. 2014, 304, 3-13. [CrossRef]

10. Dalisay, D.S.; Williams, D.E.; Wang, X.L.; Centko, R.; Chen, J.; Andersen, R.J. Marine sediment-derived Streptomyces bacteria from British Columbia, Canada are a promising microbiota resource for the discovery of antimicrobial natural products. PLoS ONE 2013, 8, e77078. [CrossRef]

11. Eltamany, E.E.; Abdelmohsen, U.R.; Ibrahim, A.K.; Hassanean, H.A.; Hentschel, U.; Ahmed, S.A. New antibacterial xanthone from the marine sponge-derived Micrococcus sp. EG45. Bioorg. Med. Chem. Lett. 2014, 24, 4939-4942. [CrossRef]

12. Abdelmohsen, U.R.; Zhang, G.L.; Philippe, A.; Schmitz, W.; Pimentel-Elardo, S.M.; Hertlein-Amslinger, B.; Hentschel, U.; Bringmann, G. Cyclodysidins A-D, cyclic lipopeptides from the marine sponge-derived Streptomyces strain RV15. Tetrahedron Lett. 2012, 53, 23-29. [CrossRef]

13. Abdelmohsen, U.R.; Szesny, M.; Othman, E.M.; Schirmeister, T.; Grond, S.; Stopper, H.; Hentschel, U. Antioxidant and anti-Protease activities of diazepinomicin from the sponge-associated Micromonospora strain RV115. Mar. Drugs 2012, 10, 2208-2221. [CrossRef] [PubMed]

14. Subramani, R.; Aalbersberg, W. Marine actinomycetes: An ongoing source of novel bioactive metabolites. Microbiol. Res. 2012, 167, 571-580. [CrossRef] [PubMed]

15. Solanki, R.; Khanna, M.; Lal, R. Bioactive compounds from marine actinomycetes. Indian J. Microbiol. 2008, 48, 410-431. [CrossRef]

16. Abdelmohsen, U.R.; Yang, C.; Horn, H.; Hajjar, D.; Ravasi, T.; Hentschel, U. Actinomycetes from Red Sea sponges: Sources for chemical and phylogenetic diversity. Mar. Drugs 2014, 12, 2771-2789. [CrossRef]

17. Grkovic, T.; Abdelmohsen, U.R.; Othman, E.M.; Stopper, H.; Edrada-Ebel, R.; Hentschel, U.; Quinn, R.J. Two new antioxidant actinosporin analogues from the calcium alginate beads culture of sponge associated Actinokineospora sp. strain EG49. Bioorg. Med. Chem. Lett. 2014, 24, 5089-5092. [CrossRef]

18. Ziemert, N.; Lechner, A.; Wietz, M.; Millan-Aguinaga, N.; Chavarria, K.L.; Jensen, P.R. Diversity, and evolution of secondary metabolism in the marine actinomycete genus Salinispora. Proc. Natl. Acad. Sci. USA 2014, 111, 1130-1139. [CrossRef]

19. Udwary, D.W.; Zeigler, L.; Asolkar, R.N.; Singan, V.; Lapidus, A.; Fenical, W.; Jensen, P.R.; Moore, B.S. Genome sequencing reveals complex secondary metabolome in the marine actinomycete Salinispora tropica. Proc. Natl. Acad. Sci. USA 2007, 104, 10376-10381. [CrossRef]

20. Marmann, A.; Aly, A.H.; Lin, W.H.; Wang, B.G.; Proksch, P. Co-Cultivation-A Powerful Emerging Tool for Enhancing the Chemical Diversity of Microorganisms. Mar. Drugs 2014, 12, 1043-1065. [CrossRef] 
21. Cimermancic, P.; Medema, M.H.; Claesen, J.; Kurita, K.; Brown, L.C.W.; Mavrommatis, K.; Pati, A.; Godfrey, P.A.; Koehrsen, M.; Clardy, J.; et al. Insights into secondary metabolism from a global analysis of prokaryotic biosynthetic gene clusters. Cell 2014, 158, 412-421. [CrossRef]

22. Abdelmohsen, U.R.; Grkovic, T.; Balasubramanian, S.; Kamel, M.S.; Quinn, R.J.; Hentschel, U. Elicitation of secondary metabolism in actinomycetes. Biotechnol. Adv. 2015, 33, 798-811. [CrossRef] [PubMed]

23. Liu, G.; Chater, K.F.; Chandra, G.; Niu, G.Q.; Tan, H.R. Molecular regulation of antibiotic biosynthesis in streptomyces. Microbiol. Mol. Biol. Rev. 2013, 77, 112-143. [CrossRef] [PubMed]

24. Ochi, K.; Hosaka, T. New strategies for drug discovery: Activation of silent or weakly expressed microbial gene clusters. Appl. Microbiol. Biotechnol. 2013, 97, 87-98. [CrossRef] [PubMed]

25. Brakhage, A.A. Regulation of fungal secondary metabolism. Nat. Rev. Microbiol. 2013, 11, 21-32. [CrossRef]

26. Rutledge, P.J.; Challis, G.L. Discovery of microbial natural products by activation of silent biosynthetic gene clusters. Nat. Rev. Microbiol. 2015, 13, 509-523. [CrossRef]

27. Letzel, A.C.; Pidot, S.J.; Hertweck, C. A genomic approach to the cryptic secondary metabolome of the anaerobic world. Nat. Prod. Rep. 2013, 30, 392-428. [CrossRef]

28. Luo, Y.; Huang, H.; Liang, J.; Wang, M.; Lu, L.; Shao, Z.; Cobb, R.E.; Zhao, H. Activation, and characterization of a cryptic polycyclic tetramate macrolactam biosynthetic gene cluster. Nat. Commun. 2013, 4, 2894. [CrossRef]

29. Zhu, H.; Sandiford, S.K.; van Wezel, G.P. Triggers and cues that activate antibiotic production by actinomycetes. J. Ind. Microbiol. Biotechnol. 2014, 41, 371-386. [CrossRef]

30. Bode, H.B.; Bethe, B.; Hofs, R.; Zeeck, A. Big effects from small changes: Possible ways to explore nature's chemical diversity. ChemBioChem 2002, 3, 619-627. [CrossRef]

31. Paranagama, P.A.; Wijeratne, E.M.K.; Gunatilaka, A.A.L. Uncovering biosynthetic potential of plant-associated fungi: Effect of culture conditions on metabolite production by Paraphaeosphaeria quadriseptata and Chaetomium chiversii. J. Nat. Prod. 2007, 70, 1939-1945. [CrossRef]

32. Wei, H.; Lin, Z.; Li, D.; Gu, Q.; Zhu, T. OSMAC (One Strain Many Compounds) approach in the research of microbial metabolites a review. Wei Sheng Wu Xue Bao 2010, 50, 701-709. [PubMed]

33. Abdelmohsen, U.R.; Cheng, C.; Viegelmann, C.; Zhang, T.; Grkovic, T.; Ahmed, S.; Quinn, R.J.; Hentschel, U.; Edrada-Ebel, R. Dereplication strategies for targeted isolation of new antitrypanosomal actinosporins A and B from a marine sponge associated-Actinokineospora sp. EG49. Mar. Drugs 2014, 12, 1220-1244. [CrossRef] [PubMed]

34. Butler, W.R.; Guthertz, L.S. Mycolic acid analysis by high-performance liquid chromatography for identification of Mycobacterium species. Clin. Microbiol. Rev. 2001, 14, 704-726. [CrossRef] [PubMed]

35. Rivera-Betancourt, O.E.; Karls, R.; Grosse-Siestrup, B.; Helms, S.; Quinn, F.; Dluhy, R.A. Identification of mycobacteria based on spectroscopic analyses of mycolic acid profiles. Analyst 2013, 138, 6774-6785. [CrossRef] [PubMed]

36. Butler, W.R.; Floyd, M.M.; Brown, J.M.; Toney, S.R.; Daneshvar, M.I.; Cooksey, R.C.; Carr, J.; Steigerwalt, A.G.; Charles, N. Novel mycolic acid-containing bacteria in the family Segniliparaceae fam. nov., including the genus Segniliparus gen. nov., with descriptions of Segniliparus rotundus sp nov and Segniliparus rugosus sp. nov. Int. J. Syst. Evol. Microbiol. 2005, 55, 1615-1624. [CrossRef] [PubMed]

37. Marrakchi, H.; Laneelle, M.A.; Daffe, M. Mycolic Acids: Structures, Biosynthesis, and Beyond. Chem. Biolog. 2014, 21, 67-85. [CrossRef] [PubMed]

38. Jamet, S.; Slama, N.; Domingues, J.; Laval, F.; Texier, P.; Eynard, N.; Quemard, A.; Peixoto, A.; Lemassu, A.; Daffe, M.; et al. The Non-Essential Mycolic Acid Biosynthesis Genes hadA and hadC Contribute to the Physiology and Fitness of Mycobacterium smegmatis. PLoS ONE 2015, 10, e0145883. [CrossRef]

39. Glickman, M.S.; Cox, J.S.; Jacobs, W.R. A novel mycolic acid cyclopropane synthetase is required for cording, persistence, and virulence of Mycobacterium tuberculosis. Mol. Cell 2000, 5, 717-727. [CrossRef]

40. Onaka, H.; Mori, Y.; Igarashi, Y.; Furumai, T. Mycolic Acid-Containing Bacteria Induce Natural-Product Biosynthesis in Streptomyces Species. Appl. Environ. Microbiol. 2011, 77, 400-406. [CrossRef]

41. Hoshino, S.; Okada, M.; Wakimoto, T.; Zhang, H.; Hayashi, F.; Onaka, H.; Abe, I. Niizalactams A-C, Multicyclic Macrolactams Isolated from Combined Culture of Streptomyces with Mycolic Acid-Containing Bacterium. J. Nat. Prod. 2015, 78, 3011-3017. [CrossRef] 
42. Hoshino, S.; Zhang, L.; Awakawa, T.; Wakimoto, T.; Onaka, H.; Abe, I. Arcyriaflavin E, a new cytotoxic indolocarbazole alkaloid isolated by combined-culture of mycolic acid-containing bacteria and Streptomyces cinnamoneus Nbrc 13823. J. Antibiotics 2015, 68, 342-344. [CrossRef] [PubMed]

43. Hoshino, S.; Wakimoto, T.; Onaka, H.; Abe, I. Chojalactones A-C, cytotoxic butanolides isolated from Streptomyces sp. cultivated with mycolic acid-containing bacterium. Org. Lett. 2015, 17, 1501-1504. [CrossRef] [PubMed]

44. Pruesse, E.; Peplies, J.; Glöckner, F.O. SINA: Accurate high-throughput multiple sequence alignment of ribosomal RNA genes. Bioinformatics 2012, 28, 1823-1829. [CrossRef] [PubMed]

45. Altschul, S.F.; Gish, W.; Miller, W.; Myers, E.W.; Lipman, D.J. Basic local alignment search tool. J. Mol. Biol. 1990, 215, 403-410. [CrossRef]

46. Stamatakis, A. RAxML version 8: A tool for phylogenetic analysis and post-analysis of large phylogenies. Bioinformatics 2014, 30, 1312-1313. [CrossRef]

47. Letunic, I.; Bork, P. Interactive Tree of Life (iTOL) v4: Recent updates and new developments. Nucleic Acids Res. 2019, 47, 256-259. [CrossRef]

48. Tawfike, A.; Attia, E.Z.; Desoukey, S.Y.; Hajjar, D.; Makki, A.A.; Schupp, P.J.; Edrada-Ebel, R.; Abdelmohsen, U.R. New bioactive metabolites from the elicited marine sponge-derived bacterium Actinokineospora spheciospongiae sp. nov. AMB Express 2019, 9, 12. [CrossRef]

49. Liu, M.; Lu, J.; Müller, P.; Turnbull, L.; Burke, C.M.; Schlothauer, R.C.; Carter, D.A.; Whitchurch, C.B.; Harry, E.J. Antibiotic-specific differences in the response of Staphylococcus aureus to treatment with antimicrobials combined with manuka honey. Fron. Microbiol. 2015, 5, 779. [CrossRef]

50. Lum, K.Y.; Tay, S.T.; Le, C.F.; Lee, V.S.; Sabri, N.H.; Velayuthan, R.D.; Hassan, H.; Sekaran, S.D. Activity of novel synthetic peptides against Candida albicans. Sci. Rep. 2015, 5, 9657. [CrossRef]

51. Kaewkla, O.; Thamchaipinet, A.; Franco, C.M.M. Micromonospora terminaliae sp. nov., an endophytic actinobacterium isolated from the surface-sterilized stem of the medicinal plant Terminalia mucronata. Int. J. Syst. Evol. Microbiol. 2017, 67, 225-230. [CrossRef]

52. Carro, L.; Nouioui, I.; Sangal, V.; Meier-Kolthoff, J.P.; Trujillo, M.E.; del Carmen Montero-Calasanz, M.; Sahin, N.; Smith, D.L.; Kim, K.E.; Peluso, P. Genome-based classification of micromonosporae with a focus on their biotechnological and ecological potential. Sci. Rep. 2018, 8, 1-23. [CrossRef] [PubMed]

53. Carro, L.; Pukall, R.; Spröer, C.; Kroppenstedt, R.M.; Trujillo, M.E. Micromonospora cremea sp. nov. and Micromonospora zamorensis sp. nov., isolated from the rhizosphere of Pisum sativum. Int. J. Syst. Evol. Microbiol. 2012, 62, 2971-2977. [CrossRef] [PubMed]

54. Kasai, H.; Tamura, T.; Harayama, S. Intrageneric relationships among Micromonospora species deduced from gyrB-based phylogeny and DNA relatedness. Int. J. Syst. Evol. Microbiol. 2000, 50, 127-134. [CrossRef] [PubMed]

55. Fang, B.; Liu, C.; Guan, X.; Song, J.; Zhao, J.; Liu, H.; Li, C.; Ning, W.; Wang, X.; Xiang, W. Two new species of the genus Micromonospora: Micromonospora palomenae sp. nov. and Micromonospora harpali sp. nov. isolated from the insects. Antonie Van Leeuwenhoek 2015, 108, 141-150. [CrossRef] [PubMed]

56. Tsang, C.-C.; Xiong, L.; Poon, R.W.; Chen, J.H.; Leung, K.-W.; Lam, J.Y.; Wu, A.K.; Chan, J.F.; Lau, S.K.; Woo, P.C. Gordonia hongkongensis sp. nov., isolated from blood culture and peritoneal dialysis effluent of patients in Hong Kong. Int. J. Syst. Evol. Microbiol. 2016, 66, 3942-3950. [CrossRef]

57. Russell, D.A.; Bustamante, C.A.G.; Garlena, R.A.; Hatfull, G.F. Complete genome sequence of Gordonia terrae 3612. Genome Announc. 2016, 4, e01058-16. [CrossRef]

58. Ivanova, N.; Sikorski, J.; Jando, M.; Lapidus, A.; Nolan, M.; Lucas, S.; Del Rio, T.G.; Tice, H.; Copeland, A.; Cheng, J.-F. Complete genome sequence of Gordonia bronchialis type strain (3410 T). Stand. Genomic Sci. 2010, 2, 19-28. [CrossRef]

59. Kim, S.B.; Brown, R.; Oldfield, C.; Gilbert, S.C.; Iliarionov, S.; Goodfellow, M. Gordonia amicalis sp. nov., a novel dibenzothiophene-desulphurizing actinomycete. Int. J. Syst. Evol. Microbiol. 2000, 50, 2031-2036. [CrossRef]

60. Shen, F.-T.; Lu, H.-L.; Lin, J.-L.; Huang, W.-S.; Arun, A.; Young, C.-C. Phylogenetic analysis of members of the metabolically diverse genus Gordonia based on proteins encoding the gyrB gene. Res. Microbiol. 2006, 157, 367-375. [CrossRef]

61. Thawai, C.; Rungjindamai, N.; Klanbut, K.; Tanasupawat, S. Nocardia xestospongiae sp. nov., isolated from a marine sponge in the Andaman Sea. Int. J. Syst. Evol. Microbiol. 2017, 67, 1451-1456. [CrossRef] 
62. Ezeoke, I.; Klenk, H.-P.; Pötter, G.; Schumann, P.; Moser, B.D.; Lasker, B.A.; Nicholson, A.; Brown, J.M. Nocardia amikacinitolerans sp. nov., an amikacin-resistant human pathogen. Int. J. Syst. Evol. Microbiol. 2013, 63, 1056-1061. [CrossRef] [PubMed]

63. Conville, P.S.; Zelazny, A.M.; Witebsky, F.G. Analysis of secA1 gene sequences for identification of Nocardia species. J. Clin. Microbiol. 2006, 44, 2760-2766. [CrossRef] [PubMed]

64. Conville, P.S.; Murray, P.R.; Zelazny, A.M. Evaluation of the Integrated Database Network System (IDNS) SmartGene software for analysis of $16 \mathrm{~S}$ rRNA gene sequences for identification of Nocardia species. J. Clin. Microbiol. 2010, 48, 2995-2998. [CrossRef] [PubMed]

65. Nett, M.; Ikeda, H.; Moore, B.S. Genomic basis for natural product biosynthetic diversity in the actinomycetes. Nat. Prod. Rep. 2009, 26, 1362-1384. [CrossRef]

66. El-Hawary, S.S.; Sayed, A.M.; Mohammed, R.; Hassan, H.M.; Zaki, M.A.; Rateb, M.E.; Mohammed, T.A.; Amin, E.; Abdelmohsen, U.R. Epigenetic Modifiers Induce Bioactive Phenolic Metabolites in the Marine-Derived Fungus Penicillium brevicompactum. Mar. Drugs 2018, 16, 253. [CrossRef]

67. Dashti, Y.; Grkovic, T.; Abdelmohsen, U.R.; Hentschel, U.; Quinn, R.J. Actinomycete Metabolome Induction/Suppression with N-Acetylglucosamine. J. Nat. Prod. 2017, 80, 828-836. [CrossRef]

68. Dinesh, R.; Srinivasan, V.; Sheeja, T.E.; Anandaraj, M.; Srambikkal, H. Endophytic actinobacteria: Diversity, secondary metabolism, and mechanisms to unsilence biosynthetic gene clusters. Crit. Rev. Microbiol. 2017, 43, 546-566. [CrossRef]

69. Fujioka, K.; Furihata, K.; Shimazu, A.; Hayakawa, Y.; Seto, H. Isolation and characterization of atramycin A and atramycin B, new isotetracenone type antitumor antibiotics. J. Antibiot. 1991, 44, 1025-1028. [CrossRef]

70. Cai, Y.; Fredenhagen, A.; Hug, P.; Peter, H.H. A nitro analogue of staurosporine and other minor metabolites produced by a Streptomyces longisporoflavus strain. J. Antibiot. 1995, 48, 143-148. [CrossRef]

71. Maskey, R.P.; Grün-Wollny, I.; Laatsch, H. Resomycins AC: New Anthracyclinone Antibiotics Formed by a Terrestrial Streptomyces sp. J. Antibiot. 2003, 56, 795-800. [CrossRef]

72. Jin, W. Isolation and structure determination of mutactimycin A, a new anthracycline antibiotic. Kangshengsu 1990, 15, 399-406.

73. Osada, H.; Koshino, H.; Kudo, T.; Onose, R.; Isono, K. A new inhibitor of protein kinase C, Rk-1409 (7-oxostaurosporine). J. Antibiot. 1992, 45, 189-194. [CrossRef] [PubMed]

74. Naik, S.; Harindran, J.; Varde, A. Pimprinine, an extracellular alkaloid produced by Streptomyces CDRIL-312: Fermentation, isolation, and pharmacological activity. J. Biotechnol. 2001, 88, 1-10. [CrossRef]

75. Wei, Y.; Fang, W.; Wan, Z.; Wang, K.; Yang, Q.; Cai, X.; Shi, L.; Yang, Z. Antiviral effects against EV71 of pimprinine and its derivatives isolated from Streptomyces sp. Virol. J. 2014, 11, 195. [CrossRef]

76. Williams, D.E.; Davies, J.; Patrick, B.O.; Bottriell, H.; Tarling, T.; Roberge, M.; Andersen, R.J. Cladoniamides A- G, tryptophan-derived alkaloids produced in culture by Streptomyces uncialis. Org. Lett. 2008, 10, 3501-3504. [CrossRef] [PubMed]

77. Roscales, S.; Plumet, J. Biosynthesis and biological activity of carbasugars. Int. J. Carbohydr. Chem. 2016, 2016. [CrossRef]

78. Tang, Y.Q.; Maul, C.; Höfs, R.; Sattler, I.; Grabley, S.; Feng, X.Z.; Zeeck, A.; Thiericke, R. Gabosines L, N and O: New Carba-Sugars from Streptomyces with DNA-Binding Properties. Eur. J. Org. Chem. 2000, 149-153. [CrossRef]

79. Balitz, D.; Bush, J.; Bradner, W.; Doyle, T.; O’herron, F.; Nettleton, D. Isolation of lavendamycin a new antibiotic from Streptomyces lavendulae. J. Antibiot. 1982, 35, 259-265. [CrossRef]

80. Takahashi, E.; Beppu, T. Anew nucleosidic antibiotic AT-265. J. Antibiot. 1982, 35, 939-947. [CrossRef]

81. Ates, N.; Ilbay, G.; Sahin, D. Suppression of generalized seizures activity by intrathalamic 2-chloroadenosine application. Exp. Biol. Med. 2005, 230, 501-505. [CrossRef]

82. Takeuchi, M.; Inukai, M.; Enokita, R.; Iwado, S.; Takahashi, S.; Arai, M. Malioxamycin, a new antibiotic with spheroplast-forming activity. J. Antibiot. 1980, 33, 1213-1219. [CrossRef] [PubMed]

83. Macgowan, A.P.; Bowker, K.E.; Wootton, M.; Holt, H.A. Activity of moxifloxacin, administered once a day, against Streptococcus pneumoniae in an in vitro pharmacodynamic model of infection. Antimicrob. Agents Chemother. 1999, 43, 1560-1564. [CrossRef] [PubMed]

84. Vértesy, L.; Fehlhaber, H.W.; Kogler, H.; Schindler, P.W. Enkastines: Amadori Products with a Specific Inhibiting Action against Endopeptidase-24.11-from Streptomyces albus and by Synthesis. Liebigs Ann. 1996, 121-126. [CrossRef] 
85. Tsunakawa, M.; Kamei, H.; Konishi, M.; Miyaki, T.; Oki, T.; Kawaguchi, H. Porothramycin, a new antibiotic of the anthramycin group: Production, isolation, structure, and biological activity. J. Antibiot. 1988, 41, 1366-1373. [CrossRef]

86. Konishi, M.; Hatori, M.; Tomita, K.; Sugawara, M.; Ikeda, C.; Nishiyama, Y.; Imanishi, H.; Miyaki, T.; Kawaguchi, H. Chicamycin, a new antitumor antibiotic. J. Antibiot. 1984, 37, 191-199. [CrossRef]

87. Osada, H.; Ishinabe, K.; Yano, T.; Kajikawa, K.; Isono, K. New Pyrrolobenzodiazepine Antibiotics, RK-1441A and B I. Biological Properties. Agric. Biol. Chem. 1990, 54, 2875-2881. [CrossRef]

88. Huang, X.; He, J.; Niu, X.; Menzel, K.D.; Dahse, H.M.; Grabley, S.; Fiedler, H.P.; Sattler, I.; Hertweck, C. Benzopyrenomycin, a Cytotoxic Bacterial Polyketide Metabolite with a Benzo a pyrene-Type Carbocyclic Ring System. Angew. Chem. Int. Ed. 2008, 47, 3995-3998. [CrossRef]

89. Pham, T.H.; Gardier, A.M. Fast-acting antidepressant activity of ketamine: Highlights on brain serotonin, glutamate, and GABA neurotransmission in preclinical studies. Pharmacol. Therapeut. 2019, 58-90. [CrossRef]

90. Arai, T.; Uno, J.; Horimi, I.; Fukushima, K. Isolation of neocopiamycin A from Streptomyces hygroscopicus var. crystallogenes, the copiamycin source. J. Antibiot. 1984, 37, 103-109. [CrossRef]

91. Seiga, K.; Yamaji, K. Microbiological study of copiamycin. Appl. Environ. Microbiol. 1971, 21, $986-989$. [CrossRef]

92. Butnariu, M.; Butu, A. Functions of collateral metabolites produced by some actinomycetes. In Microbial Pathogens and Strategies for Combating them: Science, Technology, and Education; Formatex Research Center: Badajoz, Spain, 2013; pp. 1419-1425.

93. Nisbet, L.J.; Mehta, R.J.; Oh, Y.; Pan, C.H.; Phelen, C.G.; Polansky, M.J.; Shearer, M.C.; Giovenella, A.J.; Grappel, S.F. Chlorocardicin, a monocyclic $\beta$-lactam from a Streptomyces sp. J. Antibiot. 1985, 38, $133-138$. [CrossRef] [PubMed]

94. Ikushima, H.; Iguchi, E.; Kohsaka, M.; Aoki, H.; Imanaka, H. Streptomyces auranticolor sp. nov., a new anticoccidial antibiotics producer. J. Antibiot. 1980, 33, 1103-1106. [CrossRef] [PubMed]

95. Song, X.; Yuan, G.; Li, P.; Cao, S. Guanidine-containing polyhydroxyl macrolides: Chemistry, biology, and structure-activity relationship. Molecules 2019, 24, 3913. [CrossRef] [PubMed]

96. Sugawara, A.; Kubo, M.; Hirose, T.; Yahagi, K.; Tsunoda, N.; Noguchi, Y.; Nakashima, T.; Takahashi, Y.; Welz, C.; Mueller, D. Jietacins, azoxy antibiotics with potent nematocidal activity: Design, synthesis, and biological evaluation against parasitic nematodes. Eur. J. Med. Chem. 2018, 145, 524-538. [CrossRef] [PubMed]

97. Kamal, A.; Reddy, P.; Reddy, D.R. The effect of C2-fluoro group on the biological activity of DC-81 and its dimers. Bioorg. Med. Chem. Lett. 2004, 14, 2669-2672. [CrossRef] [PubMed]

98. Russotti, G.; Göklen, K.E.; Wilson, J.J. Development of a pilot-scale microfiltration harvest for the isolation of physostigmine from Streptomyces griseofuscus broth. J. Chem. Technol. Biotechnol. 1995, 63, 37-47. [CrossRef]

99. Mynderse, J.S.; O'Connor, S.C. Quiuolizine and indolizine enzyme inhibitors. U.S. Patent 4,508,901, 2 April 1985.

100. Mayer, M.; Thiericke, R. Biosynthesis of streptazolin. J. Org. Chem. 1993, 58, 3486-3489. [CrossRef]

101. Chaudhary, H.S.; Soni, B.; Shrivastava, A.R.; Shrivastava, S. Diversity and versatility of actinomycetes and its role in antibiotic production. J. Appl. Pharm. Sci. 2013, 3, S83-S94.

102. Beck, J.; Guminski, Y.; Long, C.; Marcourt, L.; Derguini, F.; Plisson, F.; Grondin, A.; Vandenberghe, I.; Vispé, S.; Brel, V. Semisynthetic neoboutomellerone derivatives as ubiquitin-proteasome pathway inhibitors. Bioorg. Med. Chem. 2012, 20, 819-831. [CrossRef]

103. Blum, S.; Groth, I.; Rohr, J.; Fiedler, H.P. Biosynthetic capacities of actinomycetes. 5. Dioxolides, novel secondary metabolites from Streptomyces tendae. J. Basic Microbiol. 1996, 36, 19-25. [CrossRef]

104. Koyama, Y.; Yokose, K.; Dolby, L.J. Isolation, characterization, and synthesis of pimprinine, pimprinethine and pimprinaphine, metabolites of Streptoverticillium olivoreticuli. Agric. Biol. Chem. 1981, 45, 1285-1287. [CrossRef]

105. Lee, H.-B.; Choi, Y.-C.; Kim, S.-U. Isolation and identification of maculosins from Streptomyces rochei 87051-3. Appl. Biol. Chem. 1994, 37, 339-342.

106. Ortiz-López, F.; Alcalde, E.; Sarmiento-Vizcaíno, A.; Díaz, C.; Cautain, B.; García, L.; Blanco, G.; Reyes, F. New 3-Hydroxyquinaldic Acid Derivatives from Cultures of the Marine Derived Actinomycete Streptomyces cyaneofuscatus M-157. Mar. Drugs 2018, 16, 371. [CrossRef] [PubMed] 
107. Massoud, M.A.; el Bialy, S.A.; Bayoumi, W.A.; el Husseiny, W.M. Synthesis of new 2-and 3-hydroxyquinoline-4-carboxylic acid derivatives as potential antioxidants. Heterocycl. Commun. 2014, 20, 81-88. [CrossRef]

108. Mori, M.; Uozumi, Y.; Kimura, M.; Ban, Y. Total syntheses of prothracarcin and tomaymycin by use of palladium catalyzed carbonylation. Tetrahedron 1986, 42, 3793-3806. [CrossRef]

109. Shimizu, K.-i.; Kawamoto, I.; Tomita, F.; Morimoto, M.; Fujimoto, K. Prothracarcin, a novel antitumor antibiotic. J. Antibiot. 1982, 35, 972-978. [CrossRef]

110. Smith, K.C.; White, R.L.; Le, Y.; Vining, L.C. Isolation of N-acetyl-3, 4-dihydroxy-L-phenylalanine from Streptomyces akiyoshiensis. J. Nat. Prod. 1995, 58, 1274-1277. [CrossRef]

111. Kannan, S. Screening for antiviral activity of Actinomycetes isolated from soil sediments. Ph.D. Thesis, Nandha College of Pharmacy, Erode, India, 2009.

112. Hurley, L.H. Pyrrolo $(1,4)$ benzodiazepine antitumor antibiotics. Comparative aspects of anthramycin, tomaymycin and sibiromycin. J. Antibiot. 1977, 30, 349-370. [CrossRef]

113. Deepika, L.; Kannabiran, K. Antagonistic activity of streptomyces vitddk1 spp.(gu223091) isolated from the coastal region of tamil nadu, India. Pharmacologyoline 2010, 1, 17-29.

114. Harada, S. New Cephalosporins. J. Chromatogr. Libr. 1989, 43, 233-257.

115. Lee, H.C.; Liou, K.; Kim, D.H.; Kang, S.-Y.; Woo, J.-S.; Sohng, J.K. Cystocin, a novel antibiotic, produced byStreptomyces sp. GCA0001: Biological activities. Arch. Pharm. Res. 2003, 26, 446-448. [CrossRef] [PubMed]

(C) 2020 by the authors. Licensee MDPI, Basel, Switzerland. This article is an open access article distributed under the terms and conditions of the Creative Commons Attribution (CC BY) license (http://creativecommons.org/licenses/by/4.0/). 